and Iris the physical rainbow); the fourth, irony and humour.

Attached is the usual list of theses defended by Arens at his examination. I mention one for its ingenuity. Ovid's Corinna is so named because the word means, and scans like, puella.

University of St. Andrews.

$$
\text { H. J. Rose. }
$$

M. N. ToD : A Selection of Greek Historical Inscriptions to the end of the fifth century B.c. Second Edition. Pp. xx + 266. Oxford: Clarendon Press, I946. Cloth, I5s. net.

THE first edition of Tod's work, indispensable to all students of Greek history, has been exhausted, and we can only be grateful to the author and publisher for this reissue. The problem which faced them was, as Mr. Tod says in his preface, whether to make a thoroughgoing revision of the whole book (adding some recently discovered inscriptions) in the light of the remarkable progress made in the thirteen years since the first edition was published, or to reissue it with some minor corrections in the text and the addition of an appendix indicating the principal discussions of the inscriptions which have appeared since. The second course has been adopted, wisely; for the former. would have caused much delay (not only in the preparation of the book, but in waiting for the completion of the excavations in the Athenian agora), and so accurate is all Mr. Tod's work that the number of even minor corrections necessary is but small. The additional bibliography is, it need hardly be said, admirable, and gives us just what we want; Mr. Tod also adds a couple of tables giving Meritt's most recent revision of the quotalists and the re-assessments for the period of the Peloponnesian wars. A most welcome book.

\section{University of Glasgow.}

A. W. Gomme.

A. B. Ramsay : Flos Malvae. Pp. rio. Cambridge: University Press, 1946. Cloth, 6s. net.

THIs is a book to delight the academic with the grace of its latinity, while the reader who has no Latin may equally enjoy the wit and poetry to be found in this self-portrait of the Happy Scholar. The Master of Magdalene speaks with the voices of Catullus and Horace, of Ovid and Martial, and everywhere displays an equal craftsmanship. The elegiacs include a characteristically charming vision of the kindly goddess Grammatice, and every page provides a pleasurable shock as we recognize some familiar phrase of everyday speech literally latinized-nuper me poteras prosternere pluma-cornibus impositum, triste Dilemma, tuisomnibus dictis tamen atque factis. Choicest of all are the poems addressed by this latter-day Horace to his friends: in the sapphics, 'Jura (ii)', and even more in the hexameters 'To G.W.H.', there is no mere adaptation of phrasing or imitation of structure; the spirit of Horace lives again and circum praecordia ludit. He tells of his escape (by Mercury's intervention) when his bicycle tries conclusions with a motor-bus: 'plenus fabarum et spretor inertiae dilecta binis dum vehor orbibus per rura securus meaque pace fruor Lalagenque canto, prostravit ingens machina'; the next stanza seems to be pursuing the theme on conventional

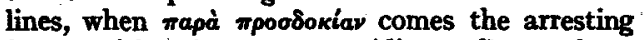
juxtaposition : 'quam paene vidi tecta Proserpinae, Annamque Reginam!

The few translations whet our appetite for more: in the three Greek pieces the translator's skill almost convinces us that the originals were entirely suitable for casting in the Greek mould: but there are two Latin versions above all which display that inevitability that is the hall-mark of the good rendering, Dean Aldrich's familiar 'Five reasons we should drink', and Housman's 'For my Funeral'.

The English half of the book includes satire (mild and bitter), and many poems inspired, like the delightful 'Magdalene', by the Master's pietas towards his School and College. The reader will

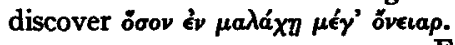

Corpus Christi College, Oxford.
F. C. Geary.

\title{
CORRESPONDENCE
}

\section{Dear Sirs,}

In a review of my Eikota $\mathrm{v}^{\prime}(C . R$., I946, p. III) the reviewer says that I have tried to defend the $e^{l} \pi c \delta^{*} \dot{a} \nu$ in Charito i. 13. 9 with instances from the fourth century. That is a false statement. I have given several examples from the second to the fourth century; but in doing so I have begun with the fourth and then gope backwards through the third to the second; I don't know why the reviewer places such authors as Hermogenes or Justin the Martyr in the fourth century. The conclusion he draws from his state- ment at the end of his review is, accordingly, quite beside the point.

\section{Yours sincerely, AlberT Wirstrand.}

\section{Lund.}

[The reviewer pleads guilty to the charge and offers his apologies to Professor Wifstrand for a careless oversight. He is not, however, persuaded that Charito did in fact write $\epsilon i{ }^{\prime} \mathrm{\tau} \delta^{\prime}$ ä $\nu$ nor does he think that his conclusion, though wrongly stated, is quite beside the point.] 